\title{
Impact of common reed and complex organic matter on the chemistry of acid sulfate soils
}

\author{
Patrick S. Michael ${ }^{1,2,3 *}$, Robert J. Reid ${ }^{1,3}$ \\ ${ }^{I}$ School of Biological Sciences, The University of Adelaide, SA 5005, Australia. ${ }^{2}$ Department of Agriculture, \\ PNG University of Technology, Lae, MP 411, Papua New Guinea. ${ }^{3}$ Acid Sulfate Soils Centre (ASSC), The \\ University of Adelaide, SA5005, Australia. ${ }^{*}$ Corresponding author: patrick.michael@pnguot.ac.pg
}

\begin{abstract}
Acid sulfate soils (ASS) are naturally occurring soils or sediments formed under reducing conditions that either contain sulfuric acid or have the potentail to form it, in an amount that can have adverse imapcts on the environment. The negative impacts of ASS are associated with the release of acidity produced and the release of toxic metals and metaloids from solubulised soil matricies into the environment. It has been shown recently that addition to ASS of dead plant material as organic matter creates microenvironments for soil microbes to ameliorate sulfuric soil and prevent sulfidic soil oxidation. Initial breakdown of the organic matter results in an oxygen demand that generates anaerobic conditions conducive to the reduction of sulfate to sulfides by sulfate reducing bacteria using the residual organic material as a carbon source and causing the $\mathrm{pH}$ to rise. There is also evidence that live plants increase acidification, potentially by aerating the soil. In nature, plants shed dead material as they grow, so that both live and dead organic matter co-exist. It is not known what happens to ASS chemistry, particularly $\mathrm{pH}$, under such natural conditions. In this study, Phragmites australis was used to examine the combined effect of growing plants and incorporated organic matter on ASS chemistry $(\mathrm{pH}$, redox potential and sulfate content) under aerobic and anaerobic conditions. In almost all cases, live plants enhanced sulfuric soil acidity and sulfidic soil oxidation. The mechanism for these changes on ASS chemistry appears to be the facilitation of oxygen penetration into the soil via aerenchymatous tissues in the plant roots.
\end{abstract}

Keywords: Acid sulfate soils, organic matter, Phragmites, $\mathrm{pH}$, redox potential, sulfate content

\section{Introduction}

In aerobic soils, cellular respiration of plant roots is supported by oxygen that reaches the rhizosphere as soils get loosened by root growth (Tinh et al.,
2001). Under anaerobic soil conditions, plants use specialized aerenchymatous structures to transport oxygen from the shoots to support root respiration 
(Armstrong, 1979). The presence of oxygen in the root zone of plants presents problems when there are oxidisable sulfides present because of the formation of sulfuric acid $\left(\mathrm{H}_{2} \mathrm{SO}_{4}\right)$. Under anaerobic, reduced soil conditions, ASS pose no problem unless the oxidisable sulfides are exposed and react with oxygen to form $\mathrm{H}_{2} \mathrm{SO}_{4}$ (Nordmyr et al., 2008). Release of the $\mathrm{H}_{2} \mathrm{SO}_{4}$ in turn dissolves the soil matrices in which iron species $\left(\mathrm{Fe}^{2+}, \mathrm{Fe}^{3+}\right)$, aluminium $\left(\mathrm{Al}^{3+}\right)$ and other potentially toxic contaminants (elements, metals or metalloids) are held, which are released into the soil and water systems (Ljung et al., 2010; Ljung et al., 2009; Åström et al., 2007). Production and propagation of $\mathrm{H}_{2} \mathrm{SO}_{4}$, and mobilisation and leaching of toxic contaminants are the major processes through which ASS pose adverse ecological impacts on the environment (Michael, 2013). Acid sulfate soils are of two types: sulfuric soil with $\mathrm{pH}<4$ and sulfidic soil with $\mathrm{pH}>4$ (Melville and White, 2012) when measured in water (soil: water solution 1:5, w/v) (Sullivan et al., 2010). In sulfuric soil, plants with aerenchymatous tissues would facilitate oxygen movement and maintain sulfuric soil acidity (Michael et al., 2017). In sulfidic soil, excessive oxygen penetration would lead to oxidation of oxidisable sulfides, generating sulfuric acidity (Michael et al., 2012). Sulfuric soil acidity has severe negative impacts on the general use and management of the environment in which ASS are present (Fitzpatrick et al., 2008; Michael, 2013). Of the estimated 17-24 million ha of ASS (Simpson and Pedini, 1985; Ljung et al., 2009), 6.5 million occur in Asia, 4.5 million in Africa, 3 million in Australia, 3 million in Latin America, 260000 in Finland, 225000 in Sweden and 100 000 in North America (Andriesse et al., 2006; Beucher et al., 2015), respectively.

In planted soil, turnover of organic matter and secretion of organic substances influence microbial activity (Muhammad et al., 2016) and alter the chemistry of soils (Shamshuddin et al., 2004; Lin et al., 2017). Several studies have shown that the addition of or- ganic matter can ameliorate sulfuric soil and stabilise the $\mathrm{pH}$ of sulfidic soil (e.g. Michael et al., 2015; Michael et al., 2016; Jayalath et al., 2016). On the other hand, Reid and Butcher (2011) found that live plants increased acidification of sulfidic soil. Under natural soil use and management conditions, plant turnover adds decaying organic matter so that both the live and dead plant material co-exist (Yan et al., 1996). It was therefore interesting to see how the combined effects of live and dead plant material would influence the main chemical soil parameters that characterise ASS: $\mathrm{pH}$, Eh and sulfate content. In this study, investigations on the changes in ASS chemistry ( $\mathrm{pH}$, Eh and sulfate content) caused by addition of dead plant material was extended using a common reed (Phragmites australis), which is often found in inland and wetland soils (Marks et al., 1994). It is known that Phragmites possesses aerenchyma which could transport oxygen into the soil (Tornberg et al., 1994) and cause problems, such as oxidation of sulfidic soil. In addition, the plant has an extensive rooting system and self-mulching effect due to rapid turnover of organic matter (Dubey and Sahu, 2014), making it ideal to assess the effects of co-existing live plants and organic matter on ASS chemistry.

\section{Materials and Methods}

\subsection{Soil}

The origin of the ASS was described in Michael et al. (2015; 2016; 2017). The sulfidic soil was collected from a "sulfuric subaqueous clayey soil" (Fitzpatrick, 2013) at a depth of approximately $1 \mathrm{~m}$ in the Finniss River in South Australia (35'24'28.28'S; 138 49'54.37'E) shown in Figure 1. Details on soil classification using the Australian ASS Identification key and Soil Taxonomy (Soil Survey Staff, 2014) are given in Table 1 as per Michael et al. (2016). In addition, a comprehensive 
list of references containing further information on the soil morphology and geochemistry prior to rewetting (i.e. sites AA26.3 and FIN26) and after reflooding (e.g. Baker et al., 2013) are given in the same table.

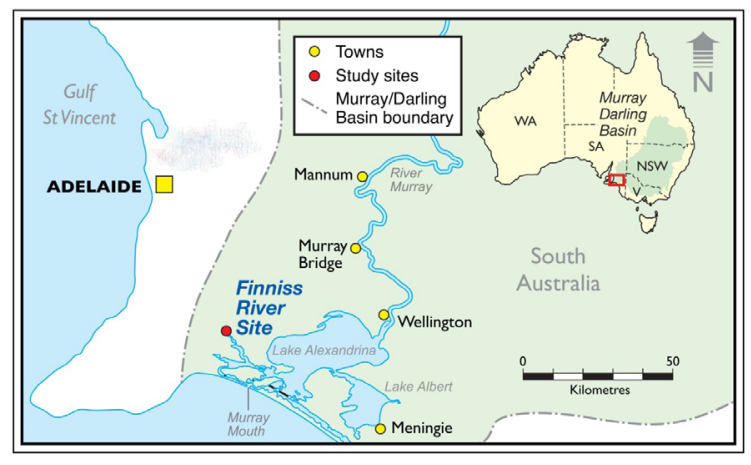

Figure 1. Locality of samples from the Finniss River site at Wally's Landing (Michael et al., 2015).

Table 1. Classification of acid sulfate soil materials from the Finniss River used in the study as per Michael et al. (2016).

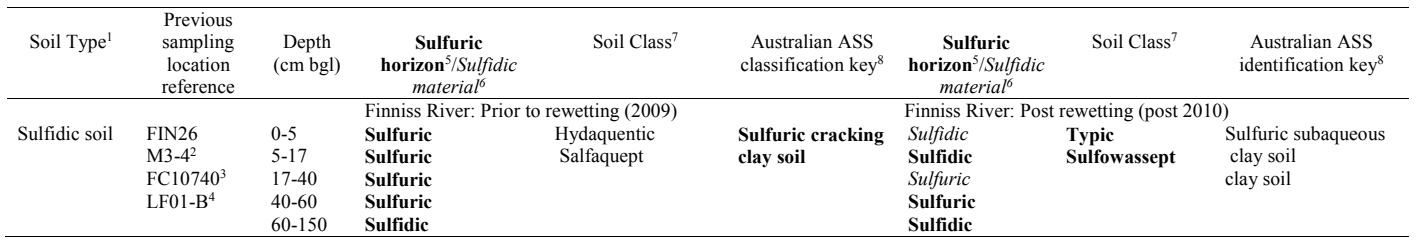

${ }^{1}$ Soil type label used in this paper when this layer of sulfidic material is used to conduct soil organic matter experiments in 70 $\mathrm{ml}$ Falcon tubes.

${ }^{2}$ Sampling location label used in (Fitzpatrick et al., 2009).

${ }^{3}$ Sampling location label used in (Fitzpatrick et al., 2011).

${ }^{4}$ Sampling location label used in (Baker et al., 2013).

${ }^{5}$ Acid sulfate soil horizon (Soil Survey Staff., 2014).

${ }^{6}$ Acid sulfate soil material (Soil Survey Staff., 2014).

${ }^{7}$ Currently no subgroup exists in Soil Taxonomy (Soil Survey Staff., 2014) that adequately describes these Finniss River soils following their rewetting. They are best described as subaqueous soils with sulfuric horizons or "Sulfuric subaqueous clayey soils" in accordance with the Australian ASS classification key (Fitzpatrick et al., 2008). Consequently, the following new proposal is currently being submitted by Fitzpatrick and Grealish (personal communication) to USDA-NRCS to consider for inclusion in revised versions of the Keys to Soil Taxonomy is: (i) a new suborder, which would be Wassepts, (ii) with the existence of Wassepts suborder, a great group of Sulfowassepts will need to be proposed within the suborder and (iii) with a the existence of Sulfowassepts great group, a subgroup of Typic Sulfowassepts will need to be proposed within the great group.

${ }^{8}$ Australian acid sulfate soil classification (Fitzpatrick et al., 2008). 
The $\mathrm{pH}$ of the freshly collected sulfidic material measured in water 1: $5\left(\mathrm{pH}_{\mathrm{w}}\right)$ was 6.7 (Table 2) and the water holding capacity was estimated to be $49 \%$. The residual organic matter content, estimated using the weight loss-on-ignition method (Schulte and Hopkins, 1996) was $10.6 \%$. The $\mathrm{pH}$ following peroxide treatment $\left(\mathrm{pH}_{\mathrm{ox}}\right)$ was 1.4. To manufacture "sulfuric horizon material" by oxidising the sulfides, the sulfidic soil was spread thinly on plastic sheets and kept moist until $\mathrm{pH}_{\mathrm{w}}$ was less than 4. The manufactured sample is henceforth referred to as "sulfuric soil" $\left(\mathrm{pH}_{\mathrm{w}}<4\right)$ and the freshly sampled sulfidic material as "sulfidic soil" $\left(\mathrm{pH}_{\mathrm{w}}>4\right)$ respectively, including the initial sulfate contents of the soils are given in Table 2.

Table 2. Descriptions of the soils from Finniss River used in the experiments.

\begin{tabular}{llll}
\hline \multirow{2}{*}{ Descriptions } & \multicolumn{3}{c}{ Experiment No. } \\
\cline { 2 - 4 } & 1 & 2 & 3 \\
\hline & Sulfuric & Sulfuric & Sulfidic \\
& soil & soil & soil \\
Initial $\mathrm{pH}_{\mathrm{w}}$ & 3.7 & 3.8 & 6.7 \\
$\mathrm{pH}_{\mathrm{ox}}$ & 2.2 & 2.7 & 1.4 \\
$\begin{array}{l}\text { Initial sulfate- } \\
\text { content range }\end{array}$ & $21-32 \mu \mathrm{mol} \mathrm{g} \mathrm{g}^{-1}$ soil & $12-16 \mu \mathrm{mol} \mathrm{g}^{-1}$ soil \\
$\begin{array}{l}\text { Experiment - } \\
\text { condition }\end{array}$ & Aerobic & Anaerobic & Anaerobic \\
\hline
\end{tabular}

Acid sulfate soil classification used in this paper is based on Australian Acid Sulfate Soil Identification key (Fitzpatrick et al., 2008).

\subsection{Organic matter and plantlets}

To use as organic matter, the first three younger and fully open leaves of $P$. australis were collected and prepared as previously described (Michael et al., 2016). All the leaves were chopped into pieces, airdried overnight under room temperature and then oven dried at $60{ }^{\circ} \mathrm{C}$ for three days. The dry pieces were finely chopped using an electric blender to pass through a $\approx 0.5 \mathrm{~mm}$ sieve. The nitrogen content of the organic matter analysed by ICP-OES using a 0.5 g samples $(n=3)$ was estimated to be $3.7 \%$. The carbon content can be approximated to be similar to grass (leaf) clippings from the data in Kamp et al. (1992). The Phragmites plants were initially raised as shoots (plantlets) by rooting rock stocks in a rooting medium (compost: sandy loam 2:1 w/w). The wellrooted plantlets used in setting the experiments were approximately 8-12 weeks old. In each treatment, two plantlets each was transplanted which produced multiple shoots throughout the experiment.

\subsection{Experiments and treatments}

Three experiments were conducted as described below with $P$. australis (common reed) plants established with organic matter incorporated in the soils (80:1, soil: organic matter w/w) by bulk mixing. Bulk mixing was done by weighing out the amount of soils or organic matter needed using a portable scale at 80:1 (w/w), and thoroughly mixed in $20 \mathrm{~L}$ mixing troughs using a spade. All the experiments were conducted in 
$50 \mathrm{~cm}$ tall $(9 \mathrm{~cm}$ in diameter) stormwater tubes whose bottom ends were tightly capped. In all the tubes, the bottom $22 \mathrm{~cm}$ was filled with sand and the top $22 \mathrm{~cm}$ with $1300 \mathrm{~g}$ of the ASS. The ASS used in all the experimental treatments was also weighed to add the exact amount in each tube. Treatments of all the experiments were replicated three times and set out in a complete randomized design under glasshouse conditions in polythene crates. In all the treatments, measurements were made only from the top $22 \mathrm{~cm}$ of ASS.

Although the 'aerobic treatments' were regularly watered daily with approximately $100 \mathrm{ml}$ of tap water, it was probable that the moisture was unevenly distributed over time, with the upper parts being aerobic and the lower parts of the profile becoming waterlogged. The anaerobic treatments were always under flooded conditions with adequate amount of water ponding on the surfaces by regular addition of water (once in the morning and in the evening).

\subsection{Measurements}

Changes in redox potential (Eh), $\mathrm{pH}$ and sulfate content were measured from the surface $(0-2 \mathrm{~cm})$, middle $(5-10 \mathrm{~cm})$ and deep $(15-20 \mathrm{~cm})$ profiles as described previously (Michael, 2015). Sulfate content was quantified using soil samples obtained from the three profile depths. Redox was measured using a single $\mathrm{Ag} / \mathrm{AgCl}$ reference and platinum $(\mathrm{Pt})$ electrode combination using an automated data logger. To measure the Eh, a handheld electric drill, with a drill bit head the size of the Pt electrode was used to make holes through the tubes with care taken to avoid disturbing the soil. The Pt electrode was inserted in the holes made using the electric drill and reference electrode inserted into the soil from the surface. This was allowed to equilibrate for $10 \mathrm{~min}$ and then Eh measured at $1 \mathrm{~min}$ intervals for the next $10 \mathrm{~min}$ and averaged (Rabenhorst et al., 2009). These values were corrected for the reference offset to be relative to the potential of a standard hydrogen electrode by adding $200 \mathrm{mV}$ (Fiedler et al., 2007). The stability and accuracy of the electrodes were maintained as per Fiedler et al. (2007). pH was measured using $2 \mathrm{~g}$ soil (1:5, soil: water) with a pre-calibrated Orion $\mathrm{pH}$ meter (720SA model).

To quantify the root biomass, the tubes were marked out at $0-2,5-10$, and $15-20 \mathrm{~cm}$, the profiles from which the changes in $\mathrm{Eh}, \mathrm{pH}$ and sulfate content in the presence of plants were measured, and cut into small sections. Soil from these sections were placed in a sieve $(0.05 \mathrm{~mm})$ and held under a gentle running tap water and the soil carefully broken up to free the roots using the aid of forceps. The loose soil particles were allowed to drain through but the roots, those that were trapped by the sieve and got floating during washing were collected. These roots were taken, gently washed again to remove soil material, placed in weighing boats and oven dried for $48 \mathrm{hrs}$. The dry weights were taken by weighing and weights of the replicates were pooled, averaged and kept as the final data.

Sulfate was extracted according to the method of Hoeft et al. (1973) for soluble soil sulfate. Replicate samples $(0.5 \mathrm{~g}$ each) were placed in tubes with $1.5 \mathrm{ml}$ of an extraction solution $\left(0.2 \mathrm{~g} \mathrm{CaH}_{2} \mathrm{PO}_{4}, 12 \mathrm{~g}\right.$ glacial acidic acid, and $88.5 \mathrm{~g}$ deionised water). After 30 min, soil was sedimented by centrifugation for $5 \mathrm{~min}$ and duplicate aliquots from the three replicates were transferred into $4 \mathrm{ml}$ cuvettes and diluted with $1.5 \mathrm{ml}$ of the extraction solution. The samples were mixed with $0.7 \mathrm{ml}$ of $0.5 \mathrm{M} \mathrm{HCl}$ and $0.7 \mathrm{ml}$ of $0.1 \mathrm{M}$ barium chloride-polyethylene glycol reagent was added and mixed again. After $10 \mathrm{~min}$, the samples were mixed again and the absorbance read at $600 \mathrm{~nm}$ using a spectrophotometer. The readings were compared to a standard solution of 0-2 $\mathrm{mM} \mathrm{Na}_{2} \mathrm{SO}_{4}$ (Michael, 2015). The initial sulfate content of the sulfuric and sulfidic 
soils respectively ranged between $21-32 \pm 0.01$ and $12-16 \pm 0.02 \mu \mathrm{mol} \mathrm{g}^{-1}$ soil.

In order to help interpret the changes in $\mathrm{pH}$ in relation to the changes in Eh, an Eh-pH range for surface environment is shown in Figure 3 and the approximate Eh range at which microbial reduction of sulfate occurs under various soil conditions is shown in Figures 2, respectively (Fiedler et al., 2007).

\subsection{Statistical analysis}

The Eh values obtained over a $10 \mathrm{~min}$ period were averaged and a treatment average obtained by taking the mean of the three replicates. Similarly, treatment average $\mathrm{pH}$ and sulfate content were obtained by taking the mean of the three replicates. To compare the treatment means, significant differences $(P<0.05)$ between treatments means of each profile was determined by two-way ANOVA using statistical software JMPIN, "AS Institute Inc. SAS Campus Drive, Cary, NC, USA 27513”. If an interaction between the treatments and profile depths was found, one-way ANOVA with all combination was performed using Tukey's HSD (honest significant difference) and pairwise comparisons.

\section{Results and Discussion}

\subsection{Effects of Phragmites plants on the chemistry of sulfuric soil}

Experiment 1: This experiment examined the changes in ASS chemistry induced by plants on sulfuric soil with incorporated organic matter under aerobic conditions (regular watering) in tubes without bottom drainage. From the Eh profile of the control soil (Figure 4c) it is clear that the soil remained aerobic down to at least $10 \mathrm{~cm}$ but increasingly anaerobic at greater depth, conditions that would favour sulfate reduction. The $\mathrm{pH}$ increases down the profile (Figure $4 \mathrm{~b}$ ) are consistent with this. In the treatment with both added organic matter and roots, the $\mathrm{pH}$ at the surface was notably higher than the control but decreased down the depth (Figure $4 b$ ), which correlates with both increased root mass (Figure 4a) and the maintenance of aerobic conditions even at depth. In both treatments there were significant reductions in sulfate content, which would be expected to occur where $\mathrm{pH}$ increases are observed, as occurred here (Figure 4d).

Experiment 2: The second experiment examined the effects of plants on soil chemistry in sulfuric soil with incorporated organic matter under anaerobic (flooded) conditions. The anaerobic conditions at all depths in the control soil (Eh near or less than $0 \mathrm{mV}$ ) resulted in $\mathrm{pH}$ increases of around 2 units (Figure 5c). In the planted treatment, the root biomass was greater towards the surface (Figure 5a). Compared to the control, Eh was much higher and $\mathrm{pH}$ significantly more acidic (Figure 5b). Again, there were large reductions in sulfate content in both treatments, consistent with the increasing $\mathrm{pH}$ (Figure 5d).

\subsection{Effects of Phragmites plants on the chemistry of sulfidic soil}

Experiment 3: This study assessed the impact of organic matter and live plants on neutral sulfidic soil under conditions similar to those described for Experiment 2. In the control soil, the Eh (Figure 6c) was highly reduced and becoming more negative at depth. These changes correlate well with the observed increase in $\mathrm{pH}$ down the profile (Figure 6b). In the planted treatment, roots were evenly distributed (Figure $6 \mathrm{a}$ ), and the Eh remained significantly higher than the control soil, consistent with the lower $\mathrm{pH}$ (Figure $6 c)$. The sulfate content of the control soil was mark- 
edly lower than in the planted soil, and roughly correlates with the differences in $\mathrm{pH}$ (Figure 6d).

Acid sulfate soils can have adverse impacts on the environment unless carefully managed (Michael, 2013). The two most common management strategies are either to neutralise the sulfuric (actual) acidity by application of mineral lime, or to prevent sulfidic soil (that has the potential to form sulfuric soil) oxidation by surface and ground water management (Baldwin and Fraser, 2009). Under general soil use and management conditions, application of lime to manage sulfuric acidity is considered expensive taken into consideration the area of land to be treated (Shamshuddin et al., 2004), and keeping sulfidic soil flooded to prevent oxidation is not desirable as very few crops can be cultivated under flooded soil (Hanhart et al., 1997). In trying to establish alternative management strategies, we recently showed that addition of organic matter in the form of chopped Phragmites leaves effectively increases the $\mathrm{pH}$ of sulfuric soil and prevents sulfidic soil oxidation (Michael et al., 2016). It was not clear from those studies, whether the observed increases in $\mathrm{pH}$ could be sustained if living plants were also present. The limited data from Reid and Butcher (2011) showed that significant acidification could result from the growing of roots of Phragmites into sulfidic soil. The acidification of the sulfidic soil resulting from oxygen pumped into the rhizosphere of the Phragmites plants through the specialised parencymatous tissues (Marks et al., 1994). The formation (genesis) of sulfuric acid from sulfides exposed to oxygen is essentially an abiotic inorganic chemical oxidation process (e.g. Lin et al., 2000):

$$
\mathrm{FeS}_{2}+3 \frac{112}{2} \mathrm{O}_{2}+3 \frac{1}{2} \mathrm{H}_{2} \mathrm{O} \rightarrow \mathrm{Fe}(\mathrm{OH})_{3}+4 \mathrm{H}^{+}+\mathrm{SO}_{4}{ }^{2-}
$$

Equation 1

At very acidic $\mathrm{pH}(<3)$, this reaction can be accelerated by bacteria such Acidothiobacillus ferrooxidans
(Valdés et al., 2008). The reverse process, reduction of sulfate to sulfides, occurs naturally very slowly, but is greatly accelerated by sulfate reducing bacteria in the absence of oxygen and with sufficient organic carbon and nitrogen for metabolism according to equation 2 (Bloomfield and Coulter, 1973).

$\mathrm{Fe}_{2} \mathrm{O}_{3}+4 \mathrm{SO}^{2-}+8 \mathrm{CH}_{2} \mathrm{O}+1 / 2 \mathrm{O}_{2} \rightarrow 2 \mathrm{FeS}_{2}+8 \mathrm{CHO}_{3-}+4 \mathrm{H}_{2} \mathrm{O}$

Equation 2

Sulfur-reducing bacteria grow optimally around $\mathrm{pH} 6$ but are still able to reduce sulfate at appreciable rates down to at least pH 3 (Luo et al., 2017).

The growth experiments demonstrated that Phragmites is very adaptable in terms of its ability to grow in soils of variable $\mathrm{pH}$ and variable oxygen availability (Figures 4-6). In the experiment described in Figure 4, the initial pH was close to 4, a level of acidity that would challenge most plants. Biomass actually increased with depth, where the control soil Eh was close to $0 \mathrm{mV}$. The most obvious impact of the roots on the soil was in the difference in Eh, with the planted soil remaining aerobic throughout the profile (Figure 4c). Clearly this can only occur if access to atmospheric oxygen is retained (Armstrong, 1979). In non-flooded soil, the root growth itself could exert a loosening effect, creating channels for oxygen diffusion (Michael et al., 2017). Perhaps more likely though, is oxygen diffusion down the channels inside the root created by aerenchymatous tissues (Marks et al., 1994; Michael et al., 2016). The fact that high Eh was also observed under flooded conditions (e.g. Figure $5 b$ ) especially within the surface soils tends to favour the idea that aerenchyma are the primary pathway of oxygen to the rhizosphere (Tornberg et al., 1994). It is important to note that the Eh is probably more representative of the bulk soil rather than the soil immediately in contact with the root where the actual Eh values may be considerably higher. 
In sulfuric soil, plants did not actually increase the acidity, they simply did not increase the $\mathrm{pH}$ as much as in the unplanted treatment. In sulfuric soil flooded with tap water and with incorporated organic matter alone, Michael et al. (2016) demonstrated $\mathrm{pH}$ increases from less than 4 to 7.5. By comparison, the combination of organic matter and live plants only increased the $\mathrm{pH}$ from round 4 to 5.6 (Figure 4b). Except in the upper profile of the sulfuric soil under aerobic (non-flooded conditions), the $\mathrm{pH}$ of both the sulfuric (Figure 5b) and sulfidic (Figure 6 b) soils containing growing plants was always more acidic than the bare control soil. This can be caused by plant roots cracking the soil which facilitated oxygen penetration, in addition to the oxygen pumped into the soil by the aerenchyma pathway (Michael et al., 2017). Under flooded conditions, the lower $\mathrm{pH}$ was consistently correlated with a higher Eh in the planted treatment (Figures 5 and 6). This was also true for the control soils where the lower Eh correlated with a higher $\mathrm{pH}$. These results are consistent with previous findings where reduced soil conditions of low Eh (Figure 4) resulted in higher $\mathrm{pH}$ and lower sulfate contents (Michael et al., 2015, 2016), confirming that sulfate reduction occurs under reduced soil condition $(0--100 \mathrm{mV})$, increasing the soil pH (Lin et al., 2003; Johnson and Hallberg, 2005). In sulfidic soil under flooded conditions, the $\mathrm{pH}$ changes were small with a slight alkalinisation (increase in $\mathrm{pH}$ ) observed in the control and a slight acidification when plants were present (Figure 6). The dominating effect here appears to be the low Eh created by the flooded conditions which prevented significant oxidation (Michael et al., 2015). Nevertheless, the differences in Eh between the treatments could explain the differences in $\mathrm{pH}$ as shown in Figure 3, and the greater decrease in sulfate concentration in the control, where the lower Eh would favour sulfate reduction as per Figure 2. One factor that has not been considered in this study is the effect of oxidation on reduction of Fe, processes that would also affect Eh and potentially the changes in states of sulfur compounds in the soil (Li et al., 2012).

In all the experiments shown in Figures 4-6, almost all the results tend to agree with the Eh-pH range of surface environments (Figure 2) and redox range of microbial reduction of sulfate (Figure 3). In the control treatments with no plants either under aerobic or anaerobic conditions, soil profiles with acidic, oxidising conditions resulted in high sulfate content (e.g. Figure 4), whereas profiles with basic, reducing conditions resulted in lower content of sulfate (Figures 5 and 6). In the planted treatment under aerobic conditions, soil profiles of higher root mass resulted in acidic, oxidising conditions with high sulfate content (Figure 4), whereas under anaerobic conditions, no clear relationship is established between the root mass and the soil chemical properties or between the $\mathrm{pH}$, Eh and sulfate content measured (Figures 5 and 6). The main reason for this being that the acidic, oxidising soil conditions (Eh $<300 \mathrm{mV}$, Figure 3) created by the oxygen pumped into the rhizosphere of the soil via the arencyma pathway (which would have resulted in an acidic, oxidising soil conditions) were consumed by the reduction reactions of the anaerobic condition created by the continuous flooding (Michael et al., 2012, 2015; 2016). 


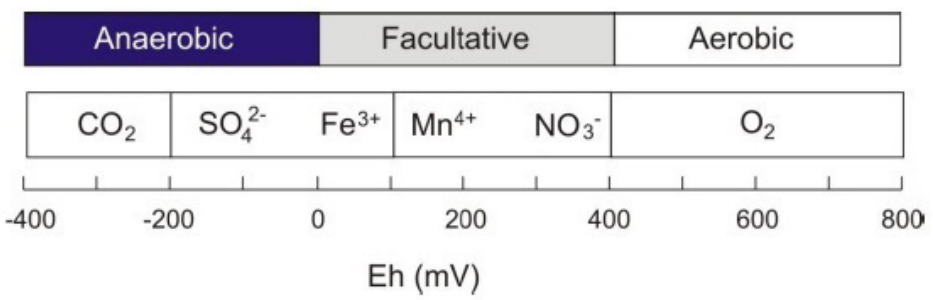

Figure 2. Approximate redox ranges for microbial energy metabolism for different electron acceptors.

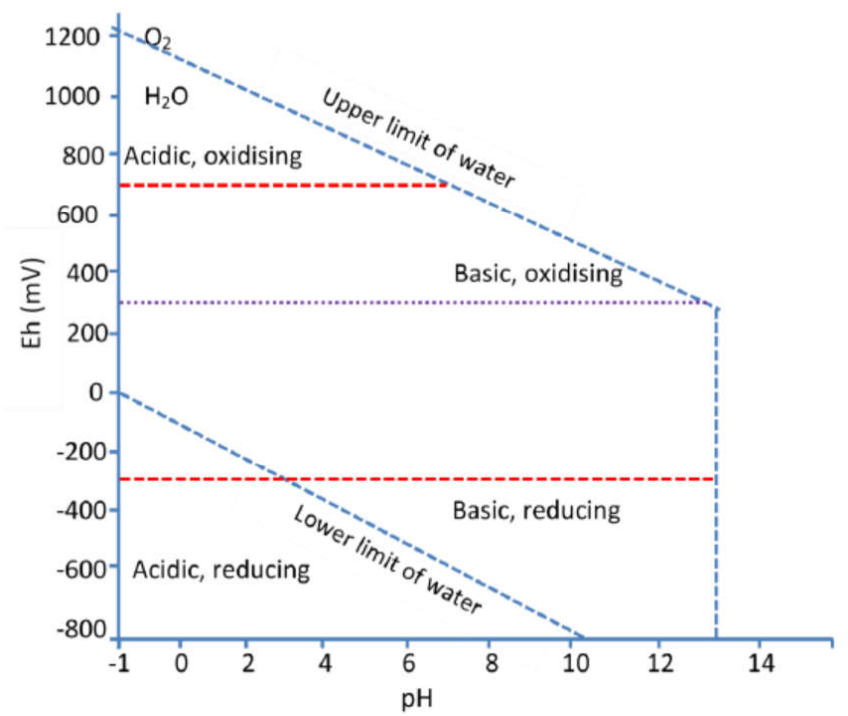

Figure 3. The Eh-pH range in surface environments showing four redox classes: (i) acidic-oxidising, (ii) basicoxidising, (iii) acidic-reducing and, (iv) basic-reducing (adapted with slight modifications from (Krauskopf, 1967) as per (Delaune and Reddy, 2005; Poch et al., 2009). The lower and upper Eh limits are shown by the red dotted lines. The purple dotted line shows the break between an aerobic and anaerobic condition (Fiedler et al., 2007). 

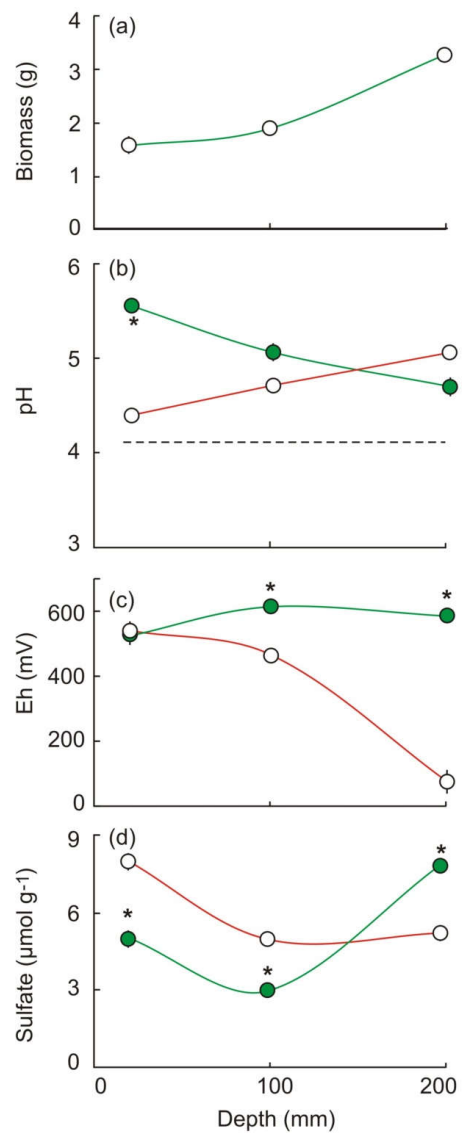

Figure 4. (a) Fresh weight of Phragmites roots at different depths and their effects on (b) $\mathrm{pH}$, (c) redox and (d) sulfate contents of sulfuric soil with organic matter maintained by regular watering for 12 months (closed symbols), compared to control soil with no plants and organic matter (open symbols). Values are means \pm s.e. of three measurements $(n=3)$. The dotted line is the initial $\mathrm{pH}$. An asterisk indicates significant difference $(P<0.05)$ between treatment and control at the same depth.
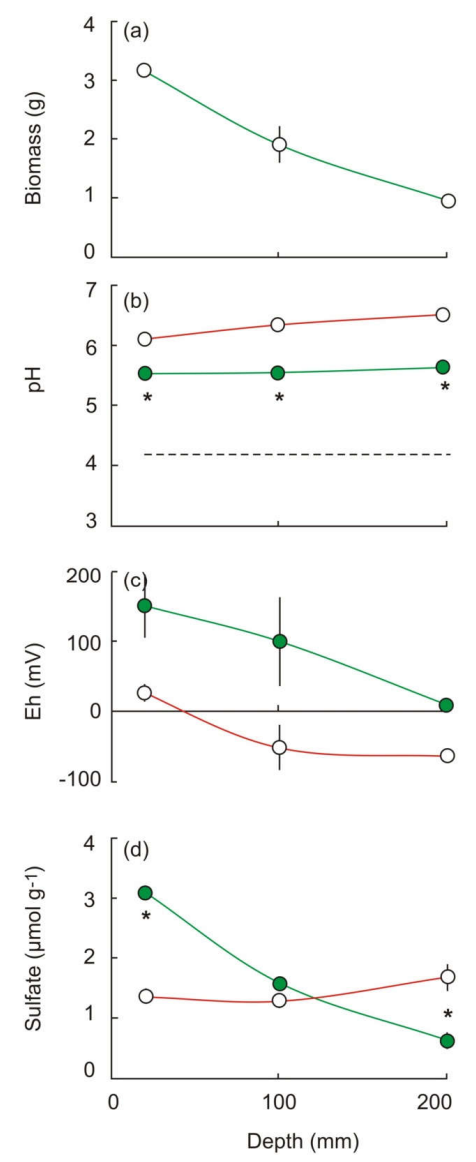

Figure 5. (a) Fresh weight of Phragmites roots at different depths and their effects on (b) $\mathrm{pH}$, (c) redox and (d) sulfate contents of sulfuric soil with organic matter maintained under anaerobic (flooded) condition for 12 months (closed symbols), compared to control soil with no plants and organic matter (open symbols). Values are means \pm s.e. of three measurements $(n=3)$. The dotted line is the initial $\mathrm{pH}$. An asterisk indicates significant difference $(P<0.05)$ between treatment and control at the same depth. 

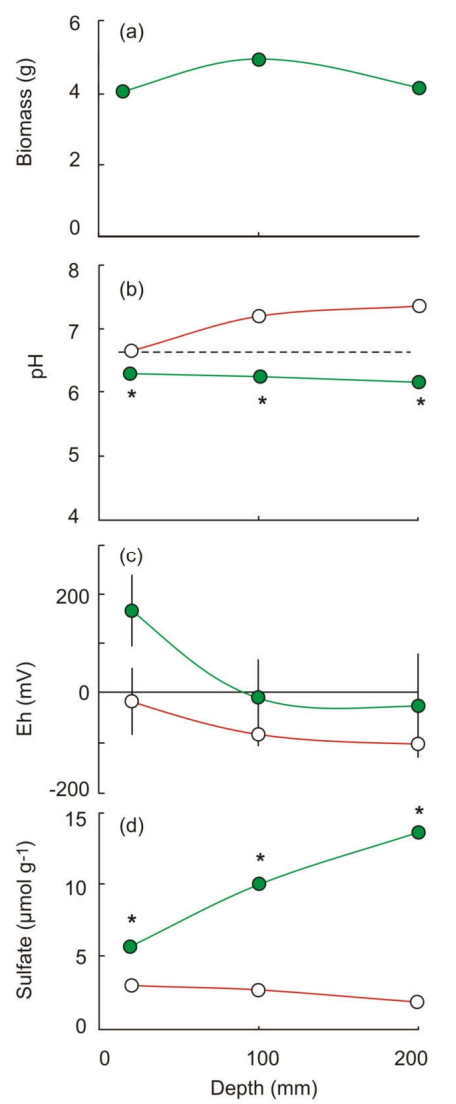

Figure 6. (a) Fresh weight of Phragmites roots at different depths and their effects on (b) $\mathrm{pH}$, (c) redox and (d) sulfate contents of sulfidic soil with organic matter maintained under anaerobic (flooded) conditions for 12 months (closed symbols), compared to control soil with no plants and organic matter (open symbols). Values are means \pm s.e. of three measurements $(n=3)$. The dotted line is the initial $\mathrm{pH}$. An asterisk indicates significant difference $(P<0.05)$ between treatment and control at the same depth.

\section{Conclusions}

The management implication is that Phragmites is a vigorous plant capable of growing in aerobic soil and also partially submerged. It is commonly associated with both inland and coastal ASS. Results from recent studies suggested that slashing large stands of Phragmites to provide surface mulch or to integrate dead shoot material into ASS would be a realistic strategy to increase the $\mathrm{pH}$ of sulfuric soil and to reduce or prevent acidification of neutral sulfidic soils. The results presented here however are consistent with our recent findings, indicating that the growth of roots of live plants has an acidifying effect and may negate the positive impacts of the dead organic matter. More work needs to be done to determine how the balance between alkalinisation by dead organic matter and acidification by live plants is influenced by the relative rates of organic matter addition and the density of growing plants. The other concern is that even if the Phragmites shoots were removed at ground level, the existing culms may still provide a conduit for oxygen diffusion into the deeper soil layers. The suitability of this strategy is also challenged by the fact that the efficacy of organic amendments is predicated on the need to keep the soil as anaerobic as possible to prevent sulfide oxidation, a condition that is not conducive to most types of agriculture.

\section{Acknowledgement}

This research was funded by the Commonwealth of Australia through an ADS scholarship provided to Patrick S. Michael. The authors thank Prof. Robert W. Fitzpatrick, Sonia Grocke and Nathan Creeper for their generous assistance provided in soil sampling and use of the redox probe. We are grateful too to the anonymous reviewers whose comments led to improvements in the manuscript. 


\section{References}

Andriesse, W., van Meensvoort, M.E.F. 2006. Acid sulfate soils: distribution and extent. In: Lal, R. (ed). Encyclopaedia of Soil Science, CRC Press, Boca Raton, Florida, pp: 14-19.

Armstrong, W. 1979. Aeration in higher plants. Adv. Bot. Res. 7, 225-332.

Baldwin, D.S., Fraser, M. 2009. Rehabilitation options for inland waterways impacted by sulfidic sediments - A synthesis. J. Environ. Manage. 91, 311-319.

Åström, M., Osterholm, P., Barlund, I., Tattari, S. 2007. Hydrochemical effects of surface liming, controlled drainage and lime-filter drainage on boreal acid sulfate soils. Water Air Soil Pollut. 179, 107-116.

Baker, A.K.M., Shand, P., Fitzpatrick, R.W. 2013. Recovery of re-flooded acid sulfate soil environments around Lakes Alexandrina and Albert, South Australia. CSIRO Water for a Healthy Country National Research Flagship, pp: 395. https://www.environment.sa.gov.au/files/4e25bdec-a4fa-4e3a-9d04-a27300f31320/recovery-reflooded-acid-sulfate-soil-lakes-2011-12-rep.pdf Accessed 30/10/2017.

Beucher, A., Fröjdö, S., Österholm, P., Auri, J., Martinkauppi, A., Edén, P. 2015. Assessment of acid sulfate soil mapping utilizing chemical indicators in recipient waters. Bull. Geol. Surv. Finland 87, 5-23.

Bloomfield, C., Coulter, J.K. 1973. Genesis and management of acid sulfate soils. Adv. Agro. 25, 265-239.

Delaune, R.D., Reddy, C.N. 2005. Redox Potential. In: Hillel, D. (ed). Encyclopedia of Soils in the Environment, Elsevier Academic Press, Amsterdam, The Netherlands, pp: 366-371.
Dubey, A.K., Sahu, O. 2014. Phragmites australis (Marsh Plant) as wastewater treatment material. Int. J. Agri. Res. Rev. 1, 48-55.

Fiedler, S., Vepraskas, M. J., Richardson, J.L. 2007. Soil redox potential: importance, field measurements, and observations. Adv. Agron. 94, 1-54.

Fitzpatrick, R.W. 2013. Demands on Soil Classification and Soil Survey Strategies: Special-Purpose Soil Classification Systems for Local Practical Use. In: Shahid, S. A., Taha, Abdelfattah, F. K. (eds). Developments in Soil Classification, Land Use Planning and Policy Implications, Springer Netherlands, pp: 51-83.

Fitzpatrick, R.W., Grealish, G.J., Shand, P., Creeper, N.L. 2011. Monitoring and assessment of reflooded Acid Sulfate Soil materials in Currency Creek and Finniss River Region, South Australia. CSIRO Sustainable Agriculture National Research Flagship. Adelaide. Client Report-325-8-6. p. 103.

http://www.clw.csiro.au/publications/science/2011/ SAF-monitoring-ASS-Currency-Creek.pdf. Accessed 30/10/2017.

Fitzpatrick, R.W., Grealish, G., Shand, P., Marvanek, S., Thomas, B.P., Creeper, N., Merry, R., Raven, M. 2009. Preliminary assessment of acid sulfate soil materials in Currency Creek, Finniss River, Tookayerta Creek and Black Swamp region, South Australia. CSIRO Land and Water Science Report 01/09, Adelaide, South Australia. http:// www.clw.csiro.au/publications/science/2009/ sr01-09.pdf.Accessed 30/10/2017.

Fitzpatrick, R., Powell, B., Marvanek, S. 2008. Atlas of Australian acid sulfate soils. In: Fitzpatrick, R. W., Paul, P. (eds). Inland Acid Sulfate Soil Systems Across Australia, CRC LEME, Perth, Australia, pp: 75-89. 
Hanhart, K., van Ni D., Bakker, N., Bil, F., van Mensvoort, M.E.F. 1997. Surface water management under varying drainage conditions for rice on an acid sulfate soil in the Mekong Delta, Vietnam. Agri. Waste Manage. 33, 99-116.

Hoeft, R.G., Walsh, L.M., Keeney, D.R. 1973. Evaluation of Various Extractants for Available Soil Sulfur1. Soil Sci. Soc. Am. J. 37, 401-404.

Jayalath, J., Mosely, L.M., Fitzpatrick, R.W., Marschner, P. 2016. Addition of organic matter influences $\mathrm{pH}$ changes in reduced and oxidised acid sulfate soils. Geoderma 262, 125-132.

Johnson, D.B., Hallberg, K.B. 2005. Acid mine drainage remediation options: a review. Sci. Total Environ. 338, 3-14.

Kamp, M.V.D., Wilson, G.B., Singley, M.E., Richard, T.L., Kolega, J.J., Gouin, F.R., Labberty, L., Kay, D., Murphy, D.W., Hartemink, H.A.J., Brintan, W.F. 1992. On-farm composting handbook. Natural Resource Agriculture and Engineering Service, Ithaca, New York.

Krauskopf, K. B. 1967. Introduction to Geochemistry. McGrawth-Hill Publisher, Pennsylvania, New York. pp: 698.

Li Y., Yu S, Strong J., Wang H. 2012. Are the biogeochemical cycles of carbon, nitrogen, sulfur, and phosphorus driven by the "FeIII-FeII redox wheel" in dynamic redox environments? J Soils Sediments 12, 683-693.

Lin, C., O'Brien, K., Lancaster, G., Sullivan, L.A., McConchie, D. 2000. An improved analytical procedure for determination of total actual acidity (TAA) in acid sulfate soils. Sci. Total Environ. 262, 57-61.

Lin, C., Haskins, P.G., Lin, J. 2003. Factors controlling deoxygenation of" floodwater" overlying an acid sulfate soil: experimental modeling. Pedosphere 13, 323-330.
Lin, G., Rui, W., Guoming, S., Jixu, Z., Guixing, M., Jiguang, Z. 2017. Effects of biochar on nutrients and microbial community structure of tobaccoplanting soils. J. Soil Sci. Plant Nutr. 17, 884-896.

Ljung, K., Maley, F., Cook, A., Weinstein, P. 2009. Acid sulphate soils and human health-A millenium ecosystem assessment. Environ. Int. 25, 1234-1242.

Ljung, K., Maley, F., Cook, A. 2010. Canal estate development in an acid sulfate soil-Implications for human metal exposure. Lansc Urban Plan. 97, 123-131.

Luo, H., Teng, W., Liu, G., Zhang, R., Lu, Y. 2017. Sulfate reduction and microbial community of autotrophic biocathode in response to acidity. Process Biochem. 54, 120-127.

Marks, M., Lapin, B., Randall, J. 1994. Phragmites australis (P. communis): threats, management and monitoring. Natural Areas J. 14, 285-294.

Melville, M.D., White, I. 2012. Acid Sulfate Soils: Management. Encyclopedia of Environmental Management. Taylor \& Francis, Salt Lake City, UT, USA, p: 6.

Michael, P.S., Reid, R., Fitzpatrick, R.W. 2012. Amelioration of slowly permeable hypersaline peatyclayey sulfuric and sulfidic materials in acid sulfate soils by mixing with friable sandy loam soil. In: Burkitt, L. L., Sparrow, L. A. (eds). Proceedings of the 5th Joint Australian and New Zealand Soil Science Conference: Soil solutions for diverse landscapes, pp: 146-149.

Michael, P.S. 2013. Ecological impacts and management of acid sulphate soil: A review. Asian J. Water, Environ. Pollut. 10, 13-24.

Michael, P.S., Fitzpatrick, R.W., Reid, R. 2015. The role of organic matter in ameliorating acid sulfate soils with sulfuric horizons. Geoderma 225, 42-49. 
Michael, P.S. 2015. Effects of alkaline sandy loam on sulfuric soil acidity and sulfidic soil oxidation. Int. J. Environ. 4, 42-54.

Michael, P.S., Fitzpatrick, R.W., Reid, R. 2016. The importance of carbon and nitrogen for amelioration of acid sulphate soils. Soil Use Manage. 32, 97-105.

Michael, P.S., Fitzpatrick, R.W., Reid, R. 2017. Effects of live wetland plant macrophytes on acidification, redox potential and sulfate content of acid sulfate soils. Soil Use Manage. 33, 471-481.

Muhammad, N., Brookes, P.C., Wu, J. 2016. Addition impact of biochar from different feed stocks on microbial community and available concentrations of elements in a Psammaquent and a Plinthudult. J. Soil Sci. Plant Nutr. 16, 137-153.

Nordmyr, L., Åström, M., Peltola, P. 2008. Metal pollution of estuarine sediments caused by leaching of acid sulphate soils. Estuar Coast Shelf Sci. 76, 141-152.

Poch, R.M., Thomas, B.P., Fitzpatrick, R.W., Merry, R.H. 2009. Micromorphological evidence for mineral weathering pathways in a coastal acid sulphate soil sequence with Mediteranean-type climate, South Australia. Aust. J. Soil Res. 47, 403-422.

Rabenhorst, M.C., Hively, W.D., James, B.R. 2009. Measurements of Soil Redox Potential. Soil Sci. Soc. Am. J. 73, 668-674.

Reid, R.J., Butcher, C.S. 2011. Positive and negative impacts of plants on acid production in exposed acid sulphate soils. Plant Soil 349, 183-190.

Schulte, E.E., Hopkins, B.G. 1996. Estimation of soil organic matter by weight loss-on-ignition. In: Magdoff, F. R., Tabatabai, M. A., Hanlon, E. A. (eds). Soil Organic Matter: Analysis and Interpretation. Soil Sci. Soc. Am. J. 21-31.
Shamshuddin, J., Muhrizal, S., Fauziah, I., Husni, M.H.A. 2004. Effects of adding organic materials to an acid sulfate soil on the growth of cocoa (Theobroma cacao L.) seedlings. Sci. Total Enviro. 323, 33-45.

Simpson, H., Pedini, P. 1985. Brackish water aquaculture in the tropics: the problem of acid sulfate soil environment. Appl. Geochem. 19, 1837-1853.

Soil Survey Staff. 2014. Keys to Soil Taxonomy. Twelfth Edition ed. United States Department of Agriculture Natural Resources Conservation Service, Washington, D.C.

Sullivan, L.A., Fitzpatrick, R.W., Bush, R.T., Burton, E.D., Shand, P., Ward, N.J. 2010. The classification of acid sulfate soil materials: further modifications. Southern Cross GeoScience Technical Report No. 310., Southern Cross University, Lismore, NSW, Australia, pp: 12.

Tinh, T.K., Huong, H.T.T., Nilsson, S.I. 2001. Ricesoil interactions in Vietnamese acid sulphate soils: impacts of submergence depth on soil solution chemistry and yields. Soil Use Manage. 17, 67-76.

Tornberg, T., Bendix, M., Brix, H. 1994. Internal gas transport in Typha latifolia L. and Typha angustifolia L. 2. Convective throughflow pathways and ecological significance. Aquat. Bot. 49, 91-105.

Valdés, J., Pedroso, I., Quatrini, R., Dodson, R.J., Tettelin, H., Blake, R., Eisen, J.A., Holmes, D.S. 2008 Acidithiobacillus ferrooxidans metabolism:from genome sequence to industrial applications. BMC Genomics 9, 597.

Yan, F., Schubert, S., Mengel, K. 1996. Soil pH changes during legume growth and application of plant materials. Biol. Fertil. Soils 23, 236-242. 